\title{
Ceramic membranes in removing boron from processed geothermal waters
}

\author{
Bilgehan Ilker Harman ${ }^{1, ~ *, ~ H a s a n ~ K o s e o g l u ~}{ }^{1}$, Nevzat Ozgu Yigit ${ }^{1}$, Nalan Kabay ${ }^{2}$, Asuman Akyuz, \\ Mehmet Kitis ${ }^{1}$
}

${ }^{1}$ Suleyman Demirel University, Dept. of Environmental Engineering, Isparta, Turkey

${ }^{2}$ Ege University, Dept. of Chemical Engineering, Izmir, Turkey

\section{Email address:}

ilkerharman@sdu.edu.tr (B. I. Harman)

\section{To cite this article:}

Bilgehan Ilker Harman, Hasan Koseoglu, Nevzat Ozgu Yigit, Nalan Kabay, Asuman Akyuz, Mehmet Kitis. Ceramic Membranes in Removing Boron from Processed Geothermal Waters. International Journal of Environmental Protection and Policy.

Vol. 2, No. 5, 2014, pp. 190-194. doi: 10.11648/j.ijepp.20140205.18

\begin{abstract}
The main objective of this work was to investigate the removal of boron from processed geothermal waters (i.e., after energy production) in lab-scale tests using ceramic ultrafiltration membranes. The impacts of membrane operating pressure, feed water $\mathrm{pH}$ and temperature and membrane pore size on boron rejections were determined. Three different single-channel tubular ceramic membrane modules with average pore sizes of $4 \mathrm{~nm}, 10 \mathrm{~nm}$ and $1 \mathrm{kD}$ were tested. Fine-UF ceramic membrane with $4 \mathrm{~nm}$ pore size provided higher boron and salt rejections than the other two tested membranes. Increasing $\mathrm{pH}$ from 8.8 to 10.5 did not enhance boron rejections. Operating pressure around 8 bar was found to be optimum in terms of flux values and boron and salt rejections for the $4 \mathrm{~nm}$ pore-sized membrane. The results indicated that ceramic ultrafiltration membranes can only partially (around 25-30\%) remove boron from geothermal waters. Once much lower pore-sized nanofiltration or brackish water reverse osmosis type ceramic membranes are available, they may be used for the desalination of processed geothermal waters since ceramic membranes are resistant to extreme conditions. Ceramic fine-UF membranes can also be used as a pre-treatment stage prior to polymeric brackish water reverse osmosis processes in desalination of geothermal waters.
\end{abstract}

Keywords: Boron, Ceramic Membrane, Desalination, Geothermal Water, Reuse

\section{Introduction}

Boron is potentially harmful in drinking water and has suspected teratogenetic properties. Male reproductive impediments of laboratory animals were affected by boron ingredients [1-4]. Boron was categorized as a pollutant in drinking water by European Union (EU). The World Health Organization (WHO) recommended boron concentration to be below $5 \mathrm{mg} / \mathrm{L}$ in drinking water. Boron concentrations in seawater and municipal wastewaters are about 5-6 mg/L [5] and $0.5-2 \mathrm{mg} / \mathrm{L}$ [6], respectively. Very high boron concentrations may be observed in geothermal waters. Various kinds of boron removal processes have been tested from different water sources including coagulation [7], electro-coagulation [8], ion exchange [9] activated carbon [10], electrodialysis [11-12], and membrane processes [13-15].

Generally polymeric membranes (nanofiltration (NF) and/or reverse osmosis (RO)) were tested or applied for boron removal from various water sources (seawater, brackish water, wastewater, and geothermal water). Boron rejections in these membrane processes depend on various factors such as solution $\mathrm{pH}$, temperature, pressure, and salt concentrations [4-6; 14; 16-17]. Boron rejections obtained by some polymeric seawater RO (SWRO) or brackish water RO (BWRO) membranes were around $99 \%$ in caustic waters $(\mathrm{pH}>9.2)$ [5; 14; 18]. Above $\mathrm{pH} 9.2$, negatively charged borate and other ions become dominant in waters which generally enhance boron rejections by various polyamide membranes [6]. However, pre-mature degradation in polymeric membranes may be observed at this high $\mathrm{pH}$ levels. In this context, ceramic membranes may be advantageous over polymeric ones due to their higher mechanical strength and resistance to extremes in $\mathrm{pH}$ and temperature and harsh chemicals [19]. Therefore, the main objectives of this work were to investigate the effectiveness 
of ceramic ultrafiltration (UF) and fine-UF membranes in rejecting boron from processed geothermal waters and to determine the impacts of operational conditions $(\mathrm{pH}$, temperature and pressure) on boron rejections. Based on the knowledge of the authors and literature search, ceramic membranes were not tested before for boron removal from waters.

\section{Materials and Methods}

Two different lab-scale, cross-flow ceramic membrane test units were used for membrane separation tests. The first test unit contained a single-channel tubular ceramic membrane module $\left(\gamma-\mathrm{Al}_{2} \mathrm{O}_{3}\right.$, Media and Process Technology, Inc., USA). Ceramic membranes with average pore sizes of 4 and $10 \mathrm{~nm}$ were tested in this unit. The outer and inner diameters of the modules were 5.7 and $3.5 \mathrm{~mm}$, respectively. The active length was $23.5 \mathrm{~cm}$. The modules had a total filtration area of $29.5 \mathrm{~cm}^{2}$. The second test unit also contained a single-channel tubular ceramic membrane module $\left(\mathrm{TiO}_{2}\right.$, Inside CeRAM, TAMI Industries, France). The molecular weight cut-off (MWCO) of this membrane was $1 \mathrm{kD}$. The outer and inner diameters of the module were 10 and $6 \mathrm{~mm}$, respectively. The active length was $25 \mathrm{~cm}$. The module had a total filtration area of $37.7 \mathrm{~cm}^{2}$. During membrane separation tests feed water temperature was kept constant at $55 \pm 2$ or $65 \pm 2{ }^{\circ} \mathrm{C}$ using a heater and resistance system immersed in the feed water tank. Detailed descriptions of the test units can be found in our previous publication [19].

Membrane tests were carried out with geothermal water samples obtained from a geothermal power plant in Kizildere, Denizli, Turkey. The temperature of the extracted geothermal water from wells in this plant is around $98{ }^{\circ} \mathrm{C}$. Collected geothermal water samples were initially cooled to room temperature and then filtered with $1-\mu \mathrm{m}$ cartridge filters prior to membrane tests. Filtered samples were collected in high-density polyethylene (HDPE) bottles and stored at room temperature until use. The physicochemical characteristics of the raw and filtered samples are shown in Table 1.

The tested membrane operating pressures were 4,8 and 12 bar. Two different feed water temperatures were tested: $55 \pm 2$ and $65 \pm 2{ }^{\circ} \mathrm{C}$. The tested feed water $\mathrm{pH}$ values were 8.8 ( $\mathrm{pH}$ of the filtered geothermal water) and 10.5. Depending on the experimental matrix, feed water $\mathrm{pH}$ values were adjusted by $\mathrm{HCl}$ and/or $\mathrm{NaOH}$ solutions and continuously monitored and controlled during the whole experiments. Total recycle mode (the concentrate and permeate streams were returned back to the feed tank) was employed in all membrane tests. The duration of each membrane test was 10 h. While flow rates of concentrate and permeate streams, membrane unit and pump outlet pressures, conductivity, $\mathrm{pH}$, and temperature were recorded each hour, the other parameters (boron, silica concentrations, etc.) were measured each $2 \mathrm{~h}$. Spectrophotometric curcumine method was employed for boron analysis. Silica and sulfate analysis were performed by spectrophotometric measurements at wavelengths of 452 and $450 \mathrm{~nm}$, respectively, using Hach DR2500 spectrophotometer. $\mathrm{pH}$ was measured using a bench-scale Schott Handylab $1 \mathrm{pH}$ meter. Conductivity and TDS was measured using WTW Inolab Cond. Level 1 conductivity meter. Distilled and deionized water was used for stock solution preparations and dilutions. All chemicals used were reagent grade.

\section{Results and Discussion}

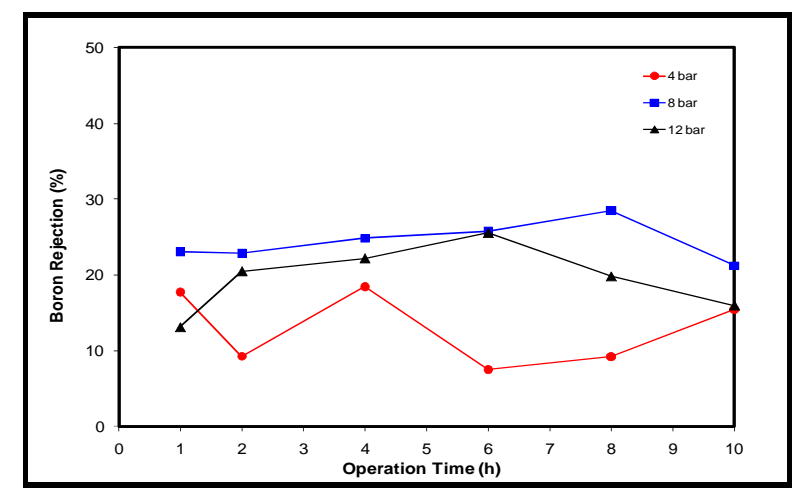

Figure 1. The impacts of membrane pressure on boron rejections $(p H=8.8$; pore size $=4 \mathrm{~nm}$; temp $=55 \pm 2{ }^{\circ} \mathrm{C}$ ).

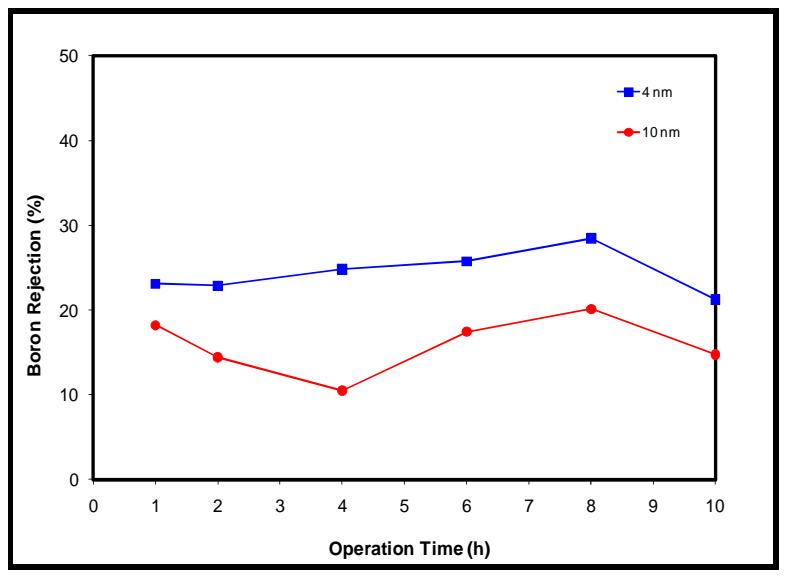

Figure 2. The impacts of membrane pore size on boron rejections ( $p H=8.8$; pressure $=8$ bar; temp $=55 \pm 2{ }^{\circ} \mathrm{C}$ ).

Fig. 1 shows the boron rejections obtained at different operating pressures using ceramic membrane with $4 \mathrm{~nm}$ average pore size. At $\mathrm{pH} 8.8$, boron rejections achieved at 4 , 8 and 12 bar were $8-19,21-29$ and $13-26 \%$, respectively. Increasing pressure from 4 to 8 bar increased rejections; however, further increasing the pressure to 12 bar deteriorated the rejections. Operating pressure around 8 bar was found to be optimum in terms of flux values and rejections for the $4 \mathrm{~nm}$ pore-sized membrane. Zhong et al [20] reported that pores of ceramic membranes could be fouled with colloidal silica or it could deposit on membrane surface. This deposit could cause the formation of cake layer on membrane surface. Also colloidal silica could form concentration polarization near the membrane surface. It is underlined that cake formation may occur when the 
convective forces are strong and the repulsive forces are weak. In this situation rejection values would be low [21]. Hence stronger convective effects may be the reason for boron leakage at 12 bar. Koseoglu et al. [14] found that for polymeric membranes boron rejections were negatively affected at higher membrane pressures (31 bar) due to concentration polarization. At $\mathrm{pH} 10.5$, boron rejections increased with increasing pressure from 4 to 8 bar for the membrane with $4 \mathrm{~nm}$ average pore size. Obtained boron rejections at 4 and 8 bar were about 12 and $25 \%$, respectively, at $\mathrm{pH} 10.5$.

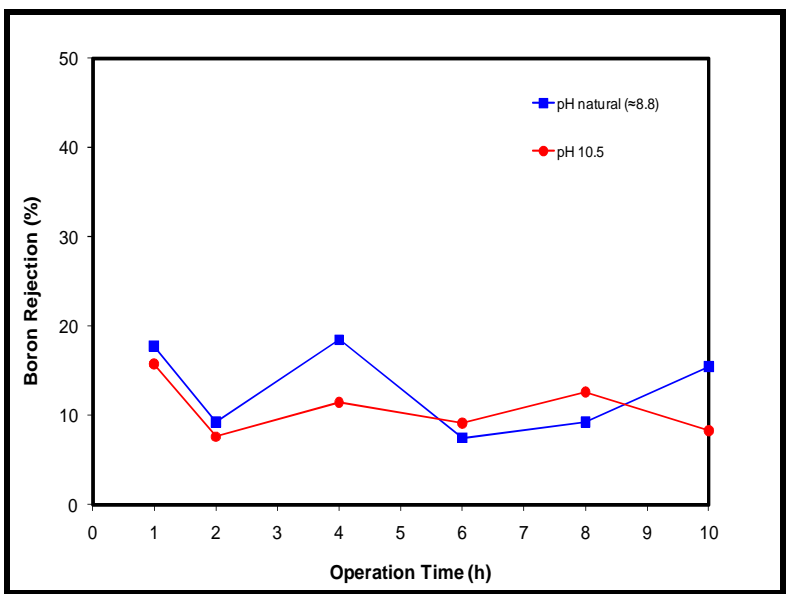

Figure 3. The impacts of feed water $p H$ on boron rejections (pressure $=4$ bar; pore size $=4 \mathrm{~nm}$; temp $=55 \pm 2{ }^{\circ} \mathrm{C}$ )

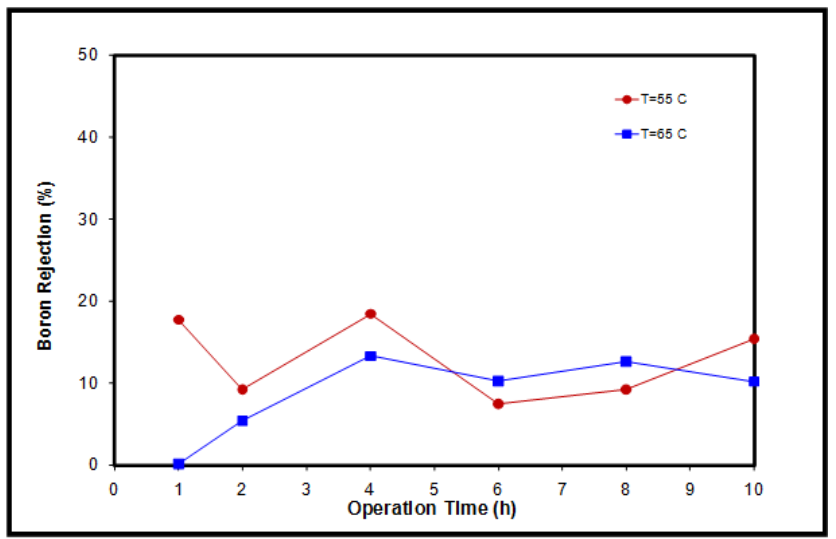

Figure 4. The impacts of feed water temperature on boron rejections $(\mathrm{pH}=8.8$; pore size $=4$ nm; pressure $=4$ bar $)$.

While maximum $20 \%$ boron rejection was achieved at 8 bar pressure with the membrane having $10 \mathrm{~nm}$ pore size, at least $21 \%$ boron rejection was obtained with the $4 \mathrm{~nm}$ pore-sized membrane at the same conditions (Fig. 2). Membrane with $4 \mathrm{~nm}$ pore size provided higher boron rejections. Boron rejections achieved by the $1 \mathrm{kD}$ ceramic membrane was the least, as expected. At pressure of 4 bar, boron rejections were $8-18$ and $1-9 \%$ with membranes having pore size of $4 \mathrm{~nm}$ and $1 \mathrm{kD}$, respectively. These results indicated that the main boron rejection mechanism is pore size exclusion at $\mathrm{pH}$ 8.8. In addition, ceramic membrane tests performed with different feed water $\mathrm{pH}$ values proved this finding. Two different feed water $\mathrm{pH}$ values were tested. Increasing the $\mathrm{pH}$ of the geothermal water from 8.8 to 10.5 did not increase boron rejections; similar boron rejection levels were observed at 4 bar pressure (Fig. 3). The boron rejections were $8-18 \%$ for $\mathrm{pH}$ 8.8 and $8-16 \%$ for $\mathrm{pH}$ 10.5. Especially for polyamide membranes, increasing solution $\mathrm{pH}$ above the $\mathrm{pKa}$ value (9.2) generally increases boron rejections since negatively charged boron species dominate and the membrane surfaces also become negatively charged at higher $\mathrm{pH}$ values. This trend was not found for the tested ceramic membranes since their material thus surface characteristics are different than those of polymeric membranes. Furthermore, high conductivity levels in the geothermal water may overwhelm the surface charge of ceramic membranes at higher $\mathrm{pH}$ values. These results overall indicated that the major boron rejection mechanism in the tested ceramic membranes was pore size exclusion at both $\mathrm{pH}$ values (8.8 and 10.5). Same trend was also found at 8 bar pressure.

Figure 4 shows the effects of feed water temperature on boron rejections. Increasing the temperature of the geothermal water at $\mathrm{pH} 8.8$ from $55 \pm 2$ to $65 \pm 2{ }^{\circ} \mathrm{C}$ did not affect boron rejections; similar levels of boron rejections were obtained at both temperature values using the membrane with $4 \mathrm{~nm}$ average pore size. Similar trend was also observed at $\mathrm{pH} 10.5$.

As for the boron rejections at different operating pressures, conductivity rejections tended to increase with increasing pressure from 4 to 12 bar. While average conductivity rejection was $28 \%$ at 4 bar pressure, it increased to $49 \%$ at 12 bar (pH 8.8, $4 \mathrm{~nm}$ pore-sized membrane). Similar levels of conductivity rejections were found at $55 \pm 2$ and $65 \pm 2{ }^{\circ} \mathrm{C}$ feed water temperatures. This trend was valid for both of the $\mathrm{pH}$ values tested. As expected due to viscosity effects, permeate flux values increased with increasing geothermal water temperatures from $55 \pm 2$ to $65 \pm 2{ }^{\circ} \mathrm{C}$ for both $\mathrm{pH}$ values. At temperatures of $55 \pm 2$ and $65 \pm 2{ }^{\circ} \mathrm{C}$, obtained flux values were $15-22$ and $22-34 \mathrm{~L} / \mathrm{m} 2-\mathrm{h}$, respectively $(\mathrm{pH} 8.8$, $4 \mathrm{~nm}$ pore-sized membrane, 4 bar pressure). For $\mathrm{pH} 10.5$, such flux values were 17-20 and 25-31 L/m2-h while the other parameters were constant.

Consistent with the trends observed for boron and conductivity, silica rejections generally increased with increasing membrane pressure. Silica rejections obtained with the $4 \mathrm{~nm}$ pore-sized membrane were 4,19 and $20 \%$ at pressures of 4,8 and 12 bar, respectively ( $\mathrm{pH} \mathrm{8.8).} \mathrm{At} \mathrm{pH}$ 10.5 , silica rejections were $13 \%$ for 4 bar and $23 \%$ for 8 bar pressure. Again as for boron and conductivity, ceramic membrane having $4 \mathrm{~nm}$ pore size was more effective than the other tested membranes in rejecting silica.

\section{Conclusions}

The ceramic membrane with $4 \mathrm{~nm}$ average pore size provided higher boron and salt rejections than the other two tested membranes (10 $\mathrm{nm}$ and $1 \mathrm{kD})$, as expected. Operating pressure around 8 bar was found to be optimum in terms of 
flux values and boron and salt rejections for the $4 \mathrm{~nm}$ pore-sized membrane. Although boron rejections were low the major boron rejection mechanism in the tested ceramic membranes was pore size exclusion at both tested $\mathrm{pH}$ values (8.8 and 10.5). Increasing $\mathrm{pH}$ from 8.8 to $10.5 \mathrm{did}$ not enhance boron rejections. High conductivity levels in the geothermal water may overwhelm the surface charge of ceramic membranes at higher $\mathrm{pH}$ values. Increasing the temperature of the geothermal water from $55 \pm 2$ to $65 \pm 2{ }^{\circ} \mathrm{C}$ did not affect boron rejections for both $\mathrm{pH}$ levels. Due to viscosity effects, permeate flux values increased with increasing geothermal water temperatures from $55 \pm 2$ to $65 \pm 2{ }^{\circ} \mathrm{C}$ for both $\mathrm{pH}$ values. At temperatures of $55 \pm 2$ and $65 \pm 2{ }^{\circ} \mathrm{C}$, obtained flux values were $15-22$ and $22-34 \mathrm{~L} / \mathrm{m}^{2}-\mathrm{h}$, respectively ( $\mathrm{pH} 8.8,4 \mathrm{~nm}$ pore-sized membrane, 4 bar pressure).

Overall, the results indicated that ceramic fine-UF membranes can only partially (around 25-30\%) remove boron from geothermal waters. The obtained boron and salt rejections are not satisfactory in terms of reuse of the processed geothermal waters (i.e., after energy production) for various reuse areas including irrigation, etc. Apparently, NF membranes with much lower pore sizes or BWRO membranes are required to obtain much higher boron rejections. However, ceramic membranes are not currently available in the market with such properties. Once much lower pore-sized NF or BWRO-type ceramic membranes are produced, they may be used for the desalination of processed geothermal waters since ceramic membranes are resistant to extreme conditions such as high temperature, low-high $\mathrm{pH}$ values, presence of solvents, acids, cleaning agents, etc. Ceramic membranes may also be advantageous over polymeric ones in terms of fouling mitigation and durability during membrane backwash/chemical cleaning procedures. Ceramic fine-UF membranes can also be used as a pre-treatment stage prior to polymeric BWRO processes in desalination of geothermal waters.

Table 1. Physicochemical characteristics of the raw and filtered (1- $\mu \mathrm{m})$ geothermal water samples (average values of duplicate measurements)

\begin{tabular}{lll}
\hline Parameter & Raw Water & $\mathbf{1}-\boldsymbol{\mu m}$ Filtration \\
\hline Temperature $\left({ }^{\circ} \mathrm{C}\right)^{\mathrm{a}}$ & 26 & 26 \\
Boron $(\mathrm{mg} / \mathrm{L})$ & 23.4 & 22.2 \\
$\mathrm{pH}$ & 8.94 & 8.80 \\
Conductivity $(\mu \mathrm{S} / \mathrm{cm})$ & 4620 & 4610 \\
TDS $(\mathrm{mg} / \mathrm{L})$ & 2402 & 2397 \\
Total iron $(\mathrm{mg} / \mathrm{L})$ & 0.03 & 0.01 \\
Sulfate $(\mathrm{mg} / \mathrm{L})$ & 900 & 840 \\
Turbidity $(\mathrm{NTU})$ & 0.59 & 0.44 \\
Total SiO $(\mathrm{mg} / \mathrm{L})$ & 287 & 262 \\
Alkalinity $\left(\mathrm{mg} / \mathrm{L} \mathrm{CaCO}{ }_{3}\right)$ & 2460 & 2350 \\
TS $(\mathrm{mg} / \mathrm{L})$ & 3722 & 3553 \\
TSS $(\mathrm{mg} / \mathrm{L})$ & 6 & $<0.2$ \\
$\mathrm{NO}_{3}-\mathrm{N}(\mathrm{mg} / \mathrm{L})$ & 1.9 & 1.4 \\
Parameter & Raw Water & $1-\mu \mathrm{m}$ Filtration \\
Temperature $\left({ }^{\circ} \mathrm{C}\right)^{\mathrm{a}}$ & 26 & 26 \\
Boron $(\mathrm{mg} / \mathrm{L})$ & 23.4 & 22.2 \\
\hline
\end{tabular}

TDS: total dissolved solids; TS: total solids; TSS: total suspended solids

${ }^{a}$ During the analytical measurements the water temperature was $26{ }^{\circ} \mathrm{C}$

\section{Acknowledgements}

This work was supported by a research grant (Project No. 2008-G0192) from BOREN (National Boron Institute of Turkey) and this support is greatly appreciated. The authors thank Media and Process Technology, Inc., USA and TAMI Industries, France for providing the ceramic membrane modules. The authors also thank Zorlu Power Plant Co. in Kızıldere, Denizli, Turkey for providing the geothermal water samples.

\section{References}

[1] Linder R.E., Strader L.F., Rehnberg G.L. (1990) Effect of acute exposure to boric acid on the male reproductive system of the rat. Journal of Toxicology Environmental Health 31, 133-146.

[2] Mastromatteo E., Sullivan F. (1994) Summary: International symposium on the health effects of boron and its compounds. Environmental Health Perspectives 102, 139-141.

[3] Magara Y., Tabata A., Kohki M., Kawasaki M., Hirose M. (1998) Development of boron reduction system for sea water desalination. Desalination 118, 25-34.

[4] Koseoglu H., Kabay N., Yuksel M., Sarp S., Arar O., Kitis M. (2008a) Boron removal from seawater using high rejection SWRO membranes - impact of $\mathrm{pH}$, feed concentration, pressure and cross-flow velocity. Desalination 227(1-3), 253-263.

[5] Kabay N., Güler E., Bryjak M. (2010) Boron in seawater and methods for its separation - A review. Desalination 261(3), 212-217.

[6] Koseoglu H., Kabay N., Yuksel M., Kitis M. (2008b) The removal of boron from model solutions and seawater using reverse osmosis membranes. Desalination 223, 126-133.

[7] Borax Consolidated Limited (1996) Report on sampling at selected water treatment works to determine the extent of boron removal by conventional water treatment.

[8] Yilmaz A.E., Boncukcuoğlu R., Kocakerim M.M., Yilmaz M.T., Paluluoğlu C. (2008) Boron removal from geothermal waters by electrocoagulation. Journal of Hazardous Materials 153, 146-151.

[9] Nadav N. (1999) Boron removal from seawater reverse osmosis permeate utilizing selective ion exchange resin. Desalination 124, 131-135.

[10] Choi W.-W., Chen K.Y. (1979) Evaluation of boron removal by adsorption on solids. Environmental Science and Technology 13(2), 189-198.

[11] Banasiak L.J., Schäfer A.I. (2009) Removal of boron, fluoride and nitrate by electrodialysis in the presence of organic matter. Journal of Membrane Science 334, 101-109.

[12] Melnik L., Vysotskaja O., Kornilovich B. (1999) Boron behavior during desalination of sea and underground water by electrodialysis. Desalination 124, 125-130.

[13] Redondo J., Busch M., De Witte J.P. (2003) Boron removal from seawater using FILMTECTM high rejection SWRO membranes. Desalination 156, 229-238. 
[14] Koseoglu H., Harman B.I., Yigit N.O., Guler E., Kabay N., Kitis M. (2010) The effects of operating conditions on boron removal from geothermal waters by membrane processes. Desalination 258, 72-78.

[15] Oo M.H., Ong, S.L. (2010) Implication of zeta potential at different salinities on boron removal by RO membranes. Jounral of Membrane Science 352, 1-6.

[16] Busch M., Mickols W.E., Jons S., Redondo J., De Witte J. (2003) Boron removal in seawater desalination. BAH03-039, IDA World Congress, Bahrain.

[17] Guler E., Piekacz J., Ozakdag D., Kujawski W., Arda M., Yuksel M., Kabay, N. (2009) Influence of chosen process parameters on the efficiency of seawater desalination: SWRO pilot plant results at Urla Bay seashore. Desalination and Water Treatment 5, 167-171.
[18] Busch M., Mickols W.E., Prabhakaran S., Lomax I., Conner J. (2005) Boron Removal at the Lowest Cost. IDA World Congress, Singapore.

[19] Harman B.I., Koseoglu H., Yigit N.O., Beyhan M., Kitis M. (2010) The use of iron oxide-coated ceramic membranes in removing natural organic matter and phenol from waters. Desalination 261, 27-33.

[20] Zhong Z., Xing W., Liu X., Jin W., Xu N. (2007) Fouling and regeneration of ceramic membranes used in recovering titanium silicalite-1 catalysts. Journal of Membrane Science 301, 67-75.

[21] Chen V., Fane A.G., Madaeni S., Wenten I.G. (1997) Particle deposition during membrane filtration of colloids: transition between concentration polarization and cake formation. Journal of Membrane Science 125, 109-122. 